\title{
Phytochemical and Pharmacological Studies of Cressa cretica-A Well-known Antioxidant
}

\section{ISSN: 2640-9208}

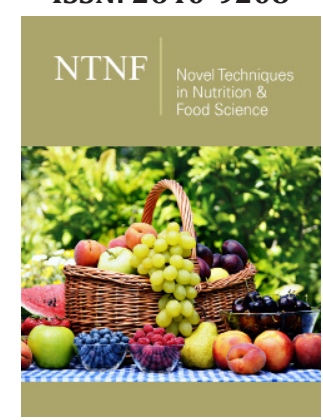

*Corresponding author: Mohammad Kamil, Zayed Complex for Herbal Research and Traditional Medicine, UAE

Submission: 価 December 11,2020

Published: 址April 07, 2021

Volume 5 - Issue 5

How to cite this article: Mohammad Kamil, F Ahmad, El T Abdallah. Phytochemical and Pharmacological Studies of Cressa Cretica-A Wellknown Antioxidant. Nov Tech Nutri Food Sci. 5(5). NTNF. 000624. 2021. DOI: 10.31031/NTNF.2021.05.000624

Copyright@ Mohammad Kamil. This article is distributed under the terms of the Creative Commons Attribution 4.0 International License, which permits unrestricted use and redistribution provided that the original author and source are credited.

\author{
Mohammad Kamil*, F Ahmad and El T Abdallah
}

Zayed Complex for Herbal Research and Traditional Medicine, UAE

\section{Mini Review}

Plant-derived antioxidants are molecules which donate electrons or hydrogen atoms. These compounds are able to form less reactive antioxidant-derived radicals, which are efficiently quenched by other electron or hydrogen sources to prevent cellular damage. Therefore, they help to delay and inhibit lipid oxidation, protect human cells against oxidative damage, leading to a reduced risk of several oxidative stress associated degenerative diseases, such as cancer, cardiovascular, or neurodegenerative diseases [1] and when added to foods tend to minimize rancidity, retard the formation of toxic oxidation products, help to maintain the nutritional quality and increase their shelf life [2].

Cressa cretica Linn. is a shrub belonging to the family Convolvulaceae which are weeds of pistachio orchards., distributed throughout middle east specially Iran, India, Timor, and Australia [3]? Very common along Abu Dhabi- Ras Al Khaima on raised sand and low dunes inland of sabkha; also, in plantations further east and north, always in sand [4]. Normally the whole plant is used as a tonic, stomachic, aphrodisiac, alterative and expectorant, and locally used for camel fodder (Fawzy Kotb, 1985). Boiled in water and taken internally as a tonic, aphrodisiac and expectorant. Dried leaves crushed with sugar taken as a treatment for jaundice [5-7]; (Figure 1).

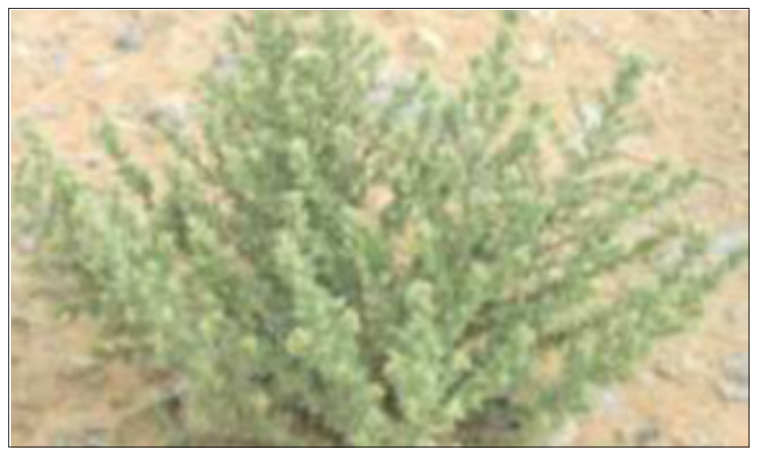

Figure 1: Phytochemistry and Pharmacognosy

Phytochemistry and Pharmacognosy

\section{Powdered plant material}

The material consists of the pounded aerial parts. It is a dark yellowish-green coarse، gritty، heterogeneous، somewhat fine powder with some comparatively larger fragments. It has a pleasant slightly spicy to straw-like odour and a salty taste. Microscopically، the powder shows numerous covering trichomes of various types and different lengths, but they are mostly long conical، tapering or broad T-shaped ones, and the majority are detached from tissues while glandular trichomes with oval to rounded heads are normally attached. The powder also shows many green fragments of the leaves at different orientations exhibiting the characteristics observed in the fresh sample. Also shown are stem fragments of dark brown bark cells with their observable thick cell walls and also long compact vascular tissues with their narrow vessels and fibers (Figure 2). 


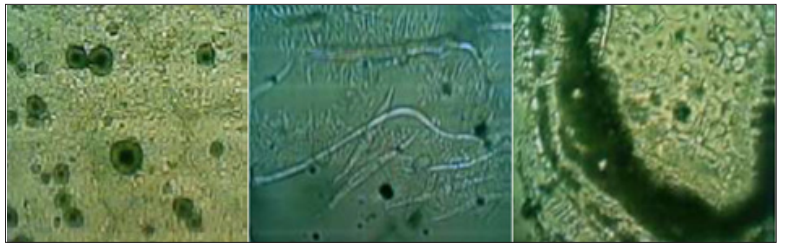

Figure 2: Parts studied: leaf and stem.

a) surface view of the leaf at the lower epidermis showing the intricate type of vascular network and some cluster crystals of calcium oxalate.

b) TS of the leaf at the lower epidermis showing long conical trichomes and T-shaped trichomes.

c) TS of the stem showing the different layers with the pith at the centre.

\section{Chemical compounds}

The isolation of syringaresinol- $\beta$-D-glucoside from Cressa cretica is reported. Coumarins، sterols quercetin and coumaranochromone glycoside [8]. N-Octocosanol ‘ $\beta$-sitosterol ‘ umbellierone، scopoletin ، isopimpinellin، $\beta$-sitosterol $D(+)$ glycoside and quercetin have been isolated [9]. The aerial parts revealed the presence of alkaloids، flavonoids، tannins، sterols and/or triterpens and coumarins [10]. The aerial parts of Cressa cretica $L$. yielded five flavonoids that were identified as: Quercetin; quercetin-3- $\beta$-O-D-glucoside; kaempferol3-0- $\beta$-D-glucoside; $\quad$ kaempferol-3-0- $\alpha$-L-rhamno-(1-+6)- $\beta$-Dglucoside; quercetin-3-0- $\alpha$-L-rhamno-(1+6)- $\beta$-D-glucoside (rutin) [11]. Aquercetin glycoside detected [12]. B-sitosterol، its glucoside، n-octacosanol، umbelliferone، scopoletin، isopimpinellin and quercetin isolated B-sitosterol، its glucoside، n-octacosanol، umbelliferone، scopoletin، isopimpinellin and quercetin isolated [13]. The following chemical studies have been carried out on the aerial part of the plant Cressa cretica.

a) Physicochemical Constants (\%)

b) Loss of weight in drying at $105^{\circ} \mathrm{C} \quad: 8.60$

c) Absolute alcohol solubility : 3.20

d) Water solubility

e) Successive extractives (\%)

f) Petroleum ether $\left(60-80^{\circ}\right)$

g) Chloroform

h) Absolute alcohol

i) Ash values (\%)

j) Total ash

k) Water soluble ash

l) Acid insoluble ash $(10 \% \mathrm{Hcl})$

m) $\mathrm{pH}$ values (aqueous solution) n) $\mathrm{pH}$ of $1 \%$ solution

$: 6.816$

o) $\mathrm{pH}$ of $10 \%$ solution

: 5.577

TLC fingerprint of Petroleum ether (60-80 ${ }^{\circ}$ track 1) and Methanol extract (track 2)

Mobile phase Figures (1\&2): Ethyl acetate, methanol, water (100:13.5:10);

C: Toluene, ethyl formate, formic acid (5:4:1)

D: Toluene, ethyl acetate (93:7)

Detection B: UV366nm

Derivatization A, C\&D: Vanillin- Sulphuric acid-vis.

\section{The pharmacological and toxicological information reported in the literature about the plant}

Cressa cretica ethanolic extract produced contraction of the isolated guinea pig ileum and the effect was inhibited by the atropine treatment. However ' the chloroform extract did not elicit any response of the muscle. Both ethanolic and chloroform extracts antagonized the effect of acetylcholine on frog's rectus abdominis muscle to the same degree (Figures 3-7). The contraction of isolated diaphragm of rat induced by electrical stimulation of phrenic nerve were also inhibited، almost completely، in the dose of $4 \mathrm{mg}$ of ethanolic extract; the effect of chloroform extract was found less than the ethanolic extract quantitatively (Tables 1 $\& 2$ ). The stimulation of sciatic nerve with $3 \mathrm{~V}$ stimulus produced an appreciable contraction of gastrocnemius muscle، but these contractions were found gradually decreased on successive stimuli after the addition of a single dose of $2 \mathrm{mg}$ of ethanolic extract or chloroform extract. These results suggest that both the ethanolic and chloroform extract possess significant neuromuscular blocking activity [14].

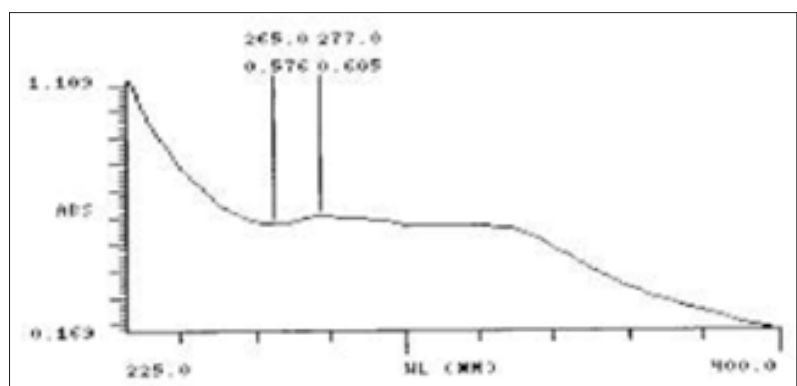

Figure 3: Intestinal Fluid simulated without pancreatic $\mathrm{pH}=7.5 \pm 0.1$.

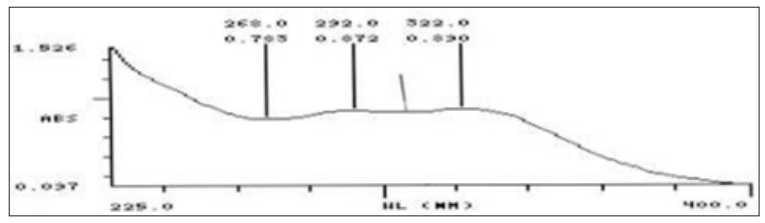

Figure 4: Fluid simulated without pepsin $\mathrm{pH}=1.2 \pm 0.1$. 


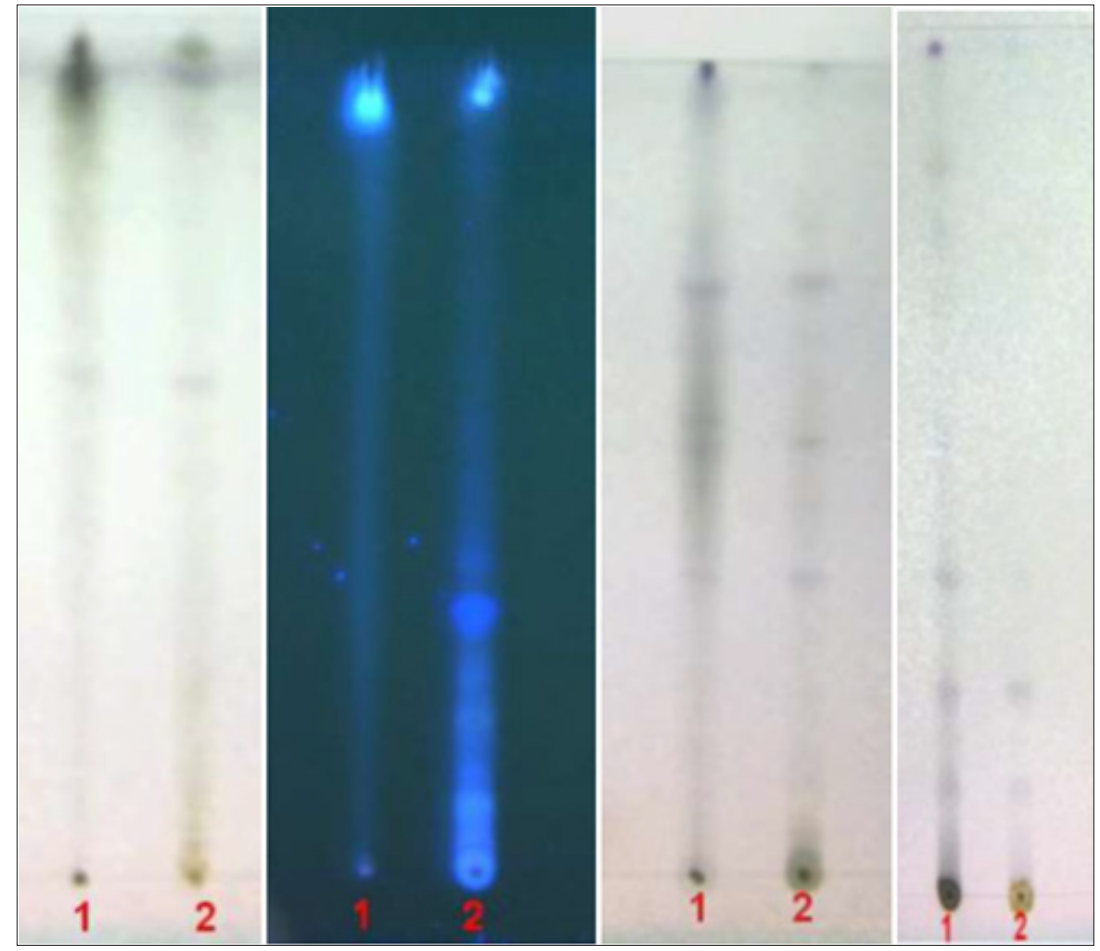

Figure 5.
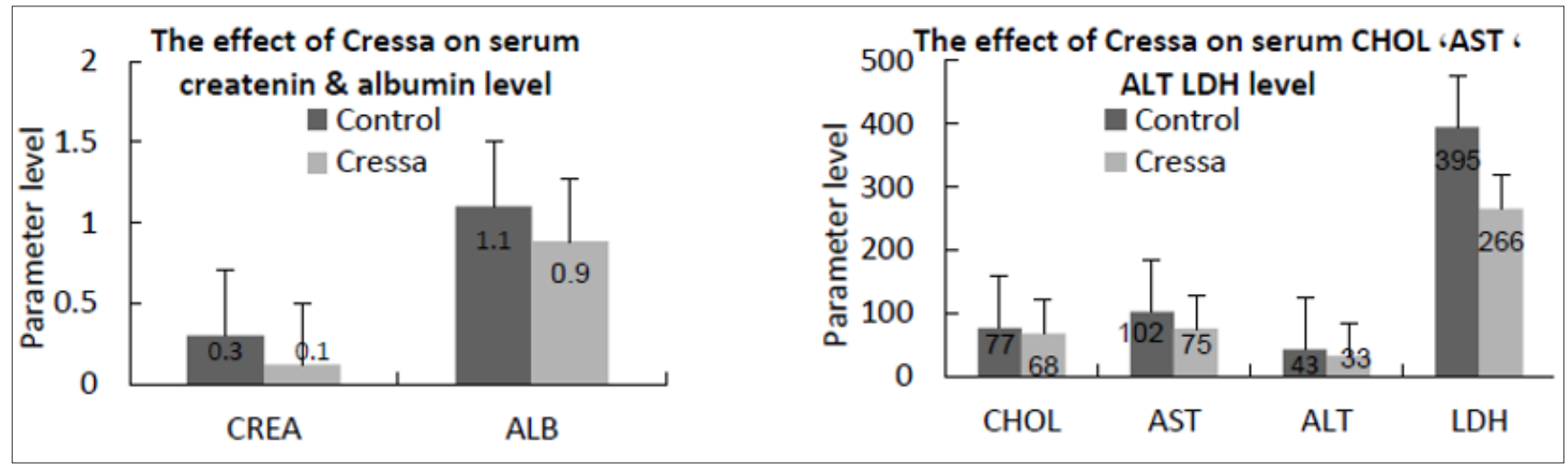

Figure 6.
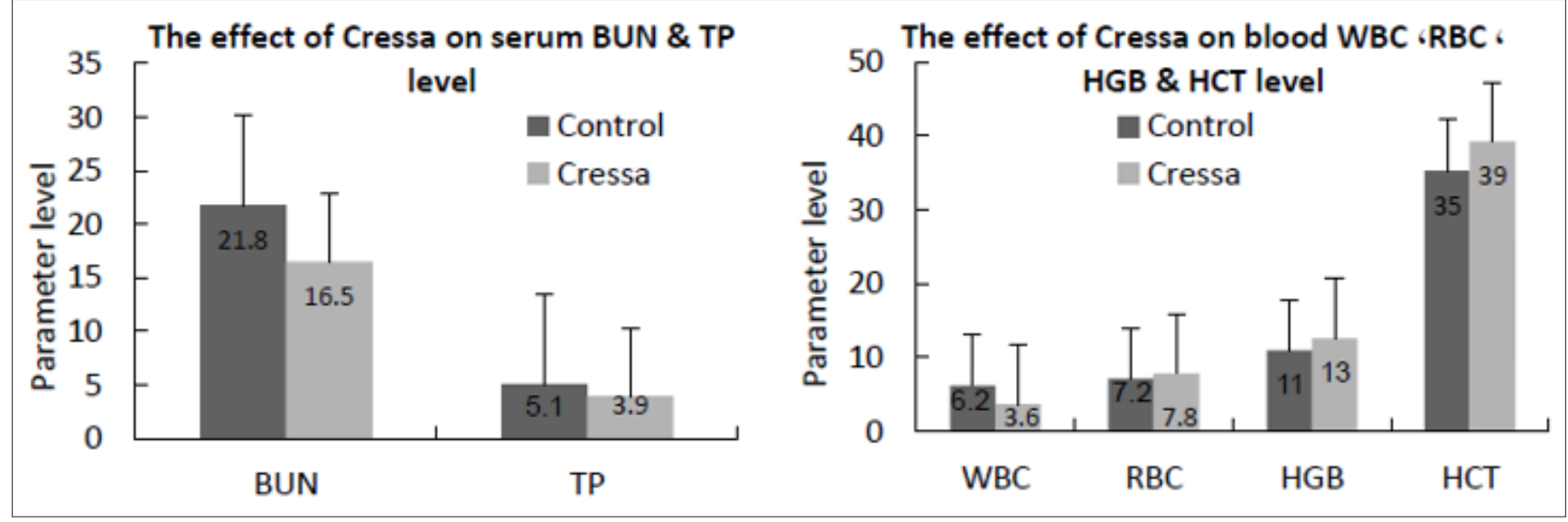

Figure 7. 
Table 1: Elemental analyses.

\begin{tabular}{|c|c|c|c|c|c|}
\hline \multicolumn{6}{|c|}{ Ash values (British Herbal Pharmacopeia-Reference) } \\
\hline \multicolumn{6}{|c|}{ Assay and identification of element (AOAC International Reference) } \\
\hline \multirow{2}{*}{$\begin{array}{l}\text { Apparatus } \\
\text { Element }\end{array}$} & \multicolumn{5}{|c|}{ (AA-6800 Shimadzu-Flame method) } \\
\hline & Std. conc. $\mu \mathrm{g} / \mathrm{ml}(\mathrm{ppm})$ & Sample conc. mg/ml & Sample's absorbance & Actual conc. mg/ml & Actual conc. $(\%)$ \\
\hline $\mathrm{Cr}$ & $1 ، 2 ، 4$ & 20.002 & 0.003 & 0.02155 & 0.02155 \\
\hline $\mathrm{Zn}$ & $0.5 ، 1 ، 2$ & 20.002 & 0.2484 & 0.1190350 & 0.0119035 \\
\hline $\mathrm{Cu}$ & $0.5 \cdot 1 \cdot 2$ & 20.002 & 0.0366 & 0.01746 & 0.001746 \\
\hline $\mathrm{Fe}$ & $1 ، 2 ، 4$ & 20.002 & 0.7358 & 1.410505 & 0.1410505 \\
\hline $\mathrm{K}$ & $1 \cdot 2 ، 4$ & 20.002 & 1.8931 & 1.071255 & 0.1071255 \\
\hline $\mathrm{Pb}$ & $1 ، 2 ، 4$ & 20.002 & 0.000 & 0.000 & 0.000 \\
\hline $\mathrm{Cd}$ & $0.25 ، 0.5 ، 1$ & 20.002 & 0.0002 & 0.000035 & 0.000035 \\
\hline
\end{tabular}

$1 \mathrm{ppm}$ conc. $=1 \mu \mathrm{g} / \mathrm{ml}$; Actual conc. $(\%)=$ Actual conc. $(\mathrm{ppm}) \times 0.0001[1 \mathrm{ppm}=0.0001 \%]$

UV Spectral studies.

Table 2: UV Spectral studies.

\begin{tabular}{|c|c|c|c|c|}
\hline \multicolumn{5}{|c|}{ Ultraviolet Spectrum (USP reference) } \\
\hline Apparatus & \multicolumn{4}{|c|}{ Milton Roy Spectronic Genesys 5 Spectrophotometer-Milton Roy } \\
\hline Sample conc.(mg/ml) & Solvent & $\lambda \max (\mathrm{nm})$ & $\lambda \min (\mathrm{nm})$ & Abs. $(\lambda \max -\lambda \min )$ \\
\hline 0.98 & $\begin{array}{l}\text { Intestinal Fluid simulated without pancreatic } \\
\qquad \mathrm{pH}=7.5 \pm 0.1\end{array}$ & 277 & 265 & $0.605-0.576$ \\
\hline \multirow{2}{*}{1.014} & \multirow{2}{*}{$\begin{array}{l}\text { Gastric Fluid simulated without pepsin } \mathrm{pH} \\
\qquad=1.2 \pm 0.1\end{array}$} & 292 & 268 & $0.872-0.783$ \\
\hline & & 322 & 307 & $0.890-0.723$ \\
\hline
\end{tabular}

Cressa cretica plant was revealed as a weight reducing effect in animals [15]. On isolated rabbit heart، no significant effect of both ethanolic and chloroform extracts was observed. However، a fall in the blood pressure of anaesthetized rabbit by both the extracts was observed [16]. The fall of the blood pressure was blocked by atropine. The biochemical and hematological studies revealed that no significant changes in serum glucose، cholesterol and electrolytes levels. No appreciable changes in RBC، and WBC counts، hemoglobin levels، prothrombin time and fibrinogen levels were observed. The following pharmacological and safety evaluation studies were carried out on the aqueous extract of the plant (Cressa cretica) (Table 3).

Table 3.

\begin{tabular}{|c|c|c|c|c|}
\hline \multirow{2}{*}{ Activity } & \multicolumn{4}{|c|}{ Results } \\
\hline & Strong & Moderate & Mild & Negative \\
\hline Analgesic / writhing test & $\sqrt{ }$ & & & \\
\hline Antidepressant & & & & $\sqrt{ }$ \\
\hline Anticonvulsant & & & $\sqrt{ }$ & \\
\hline Anti-inflammatory & $\sqrt{ }$ & & & \\
\hline Gastrointestinal activity & & & & $\sqrt{ }$ \\
\hline Effect on rabbit jejunum & & $\sqrt{ }$ & & \\
\hline Effect on rat fundus & & & & $\sqrt{ }$ \\
\hline Effect on Guinea pig ileum & & & $\sqrt{ }$ & \\
\hline $\begin{array}{c}\text { Effect on Guinea pig tracheal } \\
\text { chain }\end{array}$ & & & & $\sqrt{ }$ \\
\hline
\end{tabular}

\begin{tabular}{|c|c|l|l|l|}
\hline Effect on right rat atria & $\sqrt{ }$ & & & \\
\hline Antithrombotic effect & & & $\sqrt{ }$ & \\
\hline $\begin{array}{c}\text { Studies on biochemical } \\
\text { parameters }\end{array}$ & $\sqrt{ }$ & & & \\
\hline $\begin{array}{c}\text { Studies on hematological } \\
\text { (RBC }\end{array}$ & & $\sqrt{ }$ & & \\
\hline HGB \&HCT) increased $\uparrow$ & & & & \\
\hline $\begin{array}{c}\text { Motor co-ordination (grip } \\
\text { strength }\end{array}$ & & & & $\sqrt{ }$ \\
\hline \& motor activity & & & & \\
\hline Rectal temperature & & & & $\sqrt{ }$ \\
\hline Body weight & & & & $\sqrt{ }$ \\
\hline Vital organs & & & & $\sqrt{ }$ \\
\hline Mortality & & & & $\sqrt{ }$ \\
\hline LD50=>5g/kg‘p.o & & & & \\
\hline
\end{tabular}

Result

Cressa critica plant extract produced a moderate inhibition of the isolated rabbit jejunum which revealed that the plant extract possesses pharmacological activity against diarrhea (Anti diarroheal activity/ antispsmotic activity/spsmolytic activity); showed mild anti-convulsion activity. The Effect on right isolated rat atria showed significant positive inotropic property on rat atria in vitro. Positive inotropic agents increase myocardial contractility، and are used to support cardiac function by increasing the strength of muscular contraction (Cardio tonic/cardioprotective effect/ 
myocardial stimulant) ، having a tonic effect on the heart. The plant extract was found to decrease prothrombin time as compared to the control [17-20].

No broncho-dilatory effects were found on histamine- induced tracheal chain of the Guinea pig. The plant extract did not show antinociceptive activity and also devoid of antidepressant-like effect [21-23]. The plant extract tested on ear edema method for five days treatment failed to show significant anti-inflammatory activity. The LD50 of aqueous extract of plant was found to be greater than $10 \mathrm{~g} / \mathrm{kg}$ when administered once via gastric intubation in mice. (LD50 =>5g/kg، p.o.). Repeated dose toxicity studies; $1 \mathrm{~g} / \mathrm{kg}$ ، p.o. /day for 15 days. No death was recorded from day 1 to day 10 of observation period. Following the plant extract administration at the dose of $0.5 \mathrm{~g} / \mathrm{kg}$ ، $1 \mathrm{~g} / \mathrm{kg}$ b.w. d daily for 15 days (per os.) serum BUN، CREA، TP، ALB and AST were found significantly decreased. Whereas LDH، ALT and TBIL remained unchanged. No significant change was found in any other parameters studied، as compared to the control group. In the hematology studies the plant increased the blood RBCs، HGB، HCT and decreased the WBCs، while the other hematological parameters remained normal.

\section{References}

1. Scalbert A, Manach C, Morand C, Rémésy C, Jiménez L (2005) Dietary polyphenols and the prevention of diseases. Crit Rev Food Sci Nutr 45(4): 287-306.

2. Fukumoto L, Mazza G (2000) Assessing antioxidant and prooxidant activities of phenolic compounds. J Agri Food Chem 48(8): 3597-3604.

3. Satakopan S, Karandikar G (1961) Rudanti: a pharmacognostic study. Cressa cretica Linn. J Sci Ind Res 20: 156-160.

4. Western AR (1989) The Flora of United Arab Emirates: An introduction. Publications of the UAE, UAE, p. 188

5. Jongbloed MVD, Feulner GR, Boer B, Western AR (2003) The comprehensive guide to the wildflowers of the United Arab Emirates. UAE: Environmental Research and Wildlife Development Agency (ERWDA).

6. Ghazanfar SA (1994) Handbook of Arabian medicinal plants. ( $1^{\text {st }}$ edn), CRC Press, USA, p. 88.

7. Ghazanfar SA (1994) Handbook of Arabian medicinal plants. ( $1^{\text {st }}$ edn), CRC Press, Boca Raton, USA, p. 272.
8. Shahat AA, Abdel-Azim NS, Pieters L, Vlietinck AJ (2004) Isolation and NMR spectra of syringaresinol- $\beta$-D glucoside from Cressa cretica. Fitoterapia 75(7-8): 771-773.

9. Shahina AG (1994) Handbook of Arabian medicinal plants. (1 $1^{\text {st }}$ edn), Kindle Edition. CRC Press, USA.

10. Yahya MA, Meshal IA, Mossa JS, Badr AA, Tariq M (1990) Saudi plants: A phytochemical and biological approach. King abdulaziz city for science and technology, Saudi Arabia, p. 140.

11. Adbelaaty AS, Naglaa MN, Azim A, Nahla S, Arnold JV (2005) Flavonoids from Cressa Cretica. Qatar University science journal 25: 72-77.

12. Rastogi RP, Mehrotra BN, Sinha S, Pant P, Seth R (1991) Compendium of Indian medicinal plants. Central Drug Research Institute and Publications \& Information Lucknow, India, 2: 217.

13. Rastogi RP, Mehrotra BN (1998) Compendium of Indian medicinal plants. Central Drug Research Institute and Publications \& Information, India, 5: 254.

14. Yahya TM, Meshal IA, Mossa JS (1984) Studies on Saudi plants causing neuromuscular blockade. Proc $9^{\text {th }}$ Int Cong Pharmacol (IUPHAR), London, UK.

15. Palit P, Furman BL, Gray AI (1999) Novel weight-reducing activity of Galega officinalis in mice. J Pharm Pharmacol 51(11): 1313-1319.

16. Mossa JS, Yahiya MA, Tariq M, Meshal IA (1985) Phytochemical and pharmacological investigations of some Saudi plants showing hypotensive activity. $4^{\text {th }}$ South East Asian/Western Pacefic Regional Meeting of Pharmacologist. Penang, Malaysia.

17. Ghonemy AA (1993) Encyclopedia of medicinal plants of the United Emirates. (1 ${ }^{\text {st }}$ edn). University of UAE, UAE.

18. Fawzi MK (1995) Weeds in the United Arab Emirates. University of UAE, UAE.

19. Jonbloed MV, Feulner GR, Boer B, Western AR (2003) The comprehensive guide to the wildflowers of the United Arab Emirates. Erwda, Abu Dhabi, UAE.

20. Mandaville JP (1990) Flora of Eastern Saudi Arabia. Kegan Paul International, Riyadh, Saudi Arabia.

21. Miller AG, Morris M (1988) Plants of dhofar, the southern region of oman: traditional economic and medicinal uses. Diwan of Royal Court Sultanate of Oman-Holmes, MC Dougall, Edinburgh, Scotland.

22. Western AR (1986) The flora of United Arab Emirates. An introduction. Al Ain, UAE.

23. Western AR (1989) The flora of United Arab Emirates. An introduction. Publications of the UAE, UAE. 